\title{
THE INFLUENCE OF PHYSICAL FIELDS ON KINETIC COEFFICIENTS IN THE PROCESS OF EXTRACTIING CONTAMINANTS FROM FABRIC
}

\author{
M. K. Kosheleva, M. Z. Tsintsadze \\ Department of Energy and Resource Effective Technologies, \\ Industrial Ecology and Safety, oxtpaxt@yandex.ru; \\ The Kosygin State University of Russia, Moscow, Russia
} field.

Keywords: cotton fabric; extraction; high voltage pulses; kinetics; ultrasonic

\begin{abstract}
A quantitative assessment of the influence of the ultrasonic field and electric discharges, initiated by high voltage pulses in the working solution, on the kinetic coefficients in the process of extraction of contaminants from cotton fabric. The results can be used in kinetic calculations of the intensified processes of extraction of contaminants from fabric.
\end{abstract}

The aim of the paper is to study and quantify the effect of physical fields ultrasonic field and electric discharges in a liquid initiated by high voltage pulses - on kinetic coefficients in the process of extraction of technological contaminants from cotton fabric when it is washed after mercerization.

In the chemical technology of finishing fabrics, their washing from various technological contaminants is in many respects determining the quality of the finished material by energy-consuming operation, which accompanies almost every technological stage in the chemical technology of finishing fabrics [1, 2].

Process contaminants (non-fixed dyes, printing ink, surfactants, alkali, fatty substances, etc.) are contained in the fabric not only on its surface, but also inside it, therefore, washing the fabric is, from the physicochemical point of view, the extraction of the target component (distributed substance) from the fabric [1,2].

Improving the efficiency of the washing process due to its intensification is a necessary condition to reduce the consumption of clean washing water and chemicals, in particular surfactants, the amount of wastewater, energy costs for the process [1 - 3].

In [4 - 9], mathematical models of the processes of extraction of technological contaminants from various materials, including fabrics and fibers, were developed. However, the studies of the kinetics of the mass transfer process of washing fabrics and a quantitative assessment of its intensification in different ways were practically not conducted.

A number of studies show that ultrasonic exposure allows intensifying the extraction of technological contaminants from textile materials [1 - 3].

It is also known that the effect of electric discharges makes it possible to intensify the processes of extraction of various substances, in particular, from plant materials, which is shown in a number of works $[10-12]$. There are separate publications on the intensification by this method of the processes of extraction of technological contaminants from fibrous materials, for example, in the primary processing of wool. 
A quantitative assessment of the influence of physical fields on the kinetics of the process of extracting technological contaminants from tissues is necessary because it can be used to calculate the performance of washing equipment, assess energy and energy savings, and increase the environmental safety of the intensified washing process by reducing the contamination of wastewater with chemical reagents.

In the study, the kinetic coefficients were determined on the basis of experimental washing kinetics curves obtained on model plants without intensification and with intensification of the process by selected physical fields.

The object of investigation of the effect of the ultrasonic field on the washing kinetics was a cotton fabric with a surface density of $\mathrm{M}=0.340 \mathrm{~kg} / \mathrm{m}^{2}-$ a typical medium-density cotton fabric.

Laboratory studies were carried out at the department of Processes and apparatuses of chemical technologies of the Kosygin Moscow State Technical University. The model installation was a washing bath with piezoelectric transducers fixed in the bottom and a feeding ultrasonic generator with an operating frequency of $35 \mathrm{kHz}$ and a power consumption of 90 watts.

In the experiments, washing of the cotton fabric was carried out from sodium hydroxide, since the fabric is treated with alkali in the process of its mercerization. A fabric sample was impregnated with a sodium hydroxide solution with a concentration of $100 \mathrm{~kg} / \mathrm{m}^{3}$, the impregnation time was longer than the equilibrium time, and the alkali concentration was determined by the method of back titration $[1,2]$.

On the experimental curves of the washing kinetics, two periods of the process were observed, which is typical for washing cotton fabrics of various densities from alkali both during flow and when filtering a washing solution through a fabric web $[1,2,13,14]$.

The concentration of the process contamination in the fabric in the second washing period, which was divided into 4 zones during calculations, varied from $0.1200 \mathrm{~kg} /(\mathrm{kg}$ of dry material) to $0.0364 \mathrm{~kg} /(\mathrm{kg}$ of dry material).

The kinetics of the washing process of a typical lightweight cotton fabric after mercerization under the influence of electric discharges initiated by high voltage pulses in a working washing solution, the influence of this physical field on the kinetic coefficients of mass transfer and mass conductivity were studied during alkali extraction.

The object of the study was cotton fabric with a surface density of $M=0.150 \mathrm{~kg} / \mathrm{m}^{2}-$ a typical lightweight cotton fabric after its mercerization. In experimental studies, the same methods were used as when exposed to an ultrasonic field.

The experimental studies were carried out in the laboratories of the Department of Physics of the Pyatigorsk Medical and Pharmaceutical Institute (branch of the Volgograd State Medical University) and in the laboratory of General chemical technology of the department of Processes and apparatuses of chemical technologies of the Kosygin Moscow State Technical University. To initiate an electric discharge in aqueous wash solutions with a sufficiently high conductivity, a high voltage pulse with a short front and a limited duration was used. The high-voltage generator designed and manufactured at the Pyatigorsk Medical and Pharmaceutical Institute at the Department of Physics made it possible to obtain a voltage pulse with an amplitude of up to $50 \mathrm{kV}$ with a front $t_{f}=0.1 \mu \mathrm{s}$ and a pulse duration $t_{i}=0.8 \mu \mathrm{s}$ [10-12].

Similar to the ultrasound exposure, two periods of the process were observed on the experimental washing kinetics curves, while the effect of electric discharges causes an intensification of the process in both the first and second periods of the process.

The concentration of the process contamination in the fabric in the second washing period, which was divided into 3 zones during calculations, varied from $0.0838 \mathrm{~kg} /(\mathrm{kg}$ of dry material) to $0.01925 \mathrm{~kg} /(\mathrm{kg}$ of dry material $)$. 
In [15], a modified method was developed for determining the mass transfer coefficient of material $\beta_{\mathrm{C}}$ and the dependence $k=f(u)$ from the kinetic curve of the washing process, which consists of two periods, which does not require the exclusion of external diffusion resistance in the latter case.

This method was used to calculate the kinetic coefficients of the studied fabrics during the washing process. Kinetic coefficients for washing without intensification and using the studied physical fields were calculated from the experimental kinetics curves of the process.

As noted above, two periods of the process are observed on the washing kinetics curves without intensification and with intensification by fields. From the linear section of the kinetics curves, on which the process is controlled by external diffusion and, therefore, obeys the mass transfer equation, mass transfer coefficients are determined.

The mass conductivity coefficients of the material were determined by dividing a section of the kinetic curve (at a concentration less than critical) into concentration zones, in each of which the coefficients are considered constant [15].

Tables $1-8$ show the coefficients of mass transfer and mass conductivity of the studied fabrics when they are washed without intensification and with intensification using an ultrasonic field - ultrasound and electric discharges - ED.

Tables 1, 2, 6, 7 show the calculated values of the mass transfer Bio criterion $-\mathrm{Bi}_{m}$.

The fact that the effect of the studied physical fields intensifies the washing process both in the first period and in the second is reflected in the values of the kinetic coefficients of mass transfer and mass conductivity, as can be seen from Tables $1-8$.

Table 1

\section{Mass transfer coefficients during washing without intensification and with ultrasound}

\begin{tabular}{c|c|c}
\hline Washing & with ultrasound & without ultrasound \\
\hline$\beta_{\mathrm{C}}, \mathrm{m} / \mathrm{s}$ & $4.72 \cdot 10^{-5}$ & $2.67 \cdot 10^{-5}$ \\
\hline
\end{tabular}

Table 2

Mass conductivity coefficients $k$ calculated by the zonal method for medium density cotton fabric during washing without ultrasound

\begin{tabular}{c|c|c|c|c}
\hline Concentration zone number & 1 & 2 & 3 & 4 \\
\hline $\mathrm{k}_{\mathrm{i}} \cdot 10^{9}, \mathrm{~m}^{2} / \mathrm{s}$ & 0.86 & 0.54 & 0.59 & 0.55 \\
\hline $\mathrm{Bi}_{m}$ & 24.6 & 39.4 & 36.2 & 38.8 \\
\hline
\end{tabular}

Table 3

Mass conductivity coefficients $k$ calculated by the zonal method for medium density cotton fabric during washing with ultrasound

\begin{tabular}{c|c|c|c|c}
\hline Concentration zone number & 1 & 2 & 3 & 4 \\
\hline$k_{i} \cdot 10^{9}, \mathrm{~m}^{2} / \mathrm{s}$ & 1.32 & 1.01 & 0.79 & 0.53 \\
\hline $\mathrm{Bi}_{m}$ & 28.5 & 37.36 & 47.6 & 70.6 \\
\hline
\end{tabular}


Comparison of the coefficients of mass conductivity during washing without intensification and with ultrasound

\begin{tabular}{c|c|c|c|c|c}
\hline \multicolumn{2}{c|}{ Concentration zone number } & 1 & 2 & 3 & 4 \\
\hline$k_{i} \cdot 10^{9}, \mathrm{~m}^{2} / \mathrm{s}$ & with ultrasound & 1.32 & 1.01 & 0.79 & 0.53 \\
\hline$k_{i} \cdot 10^{9}, \mathrm{~m}^{2} / \mathrm{s}$ & without ultrasound & 0.86 & 0.54 & 0.59 & 0.55 \\
\hline
\end{tabular}

Mass transfer coefficients during washing without intensification and with exposure of ED

\begin{tabular}{c|c|c}
\hline Washing & without ED & with ED \\
\hline$\beta_{\mathrm{C}}, \mathrm{m} / \mathrm{s}$ & $1,377 \cdot 10^{-5}$ & $2,55 \cdot 10^{-5}$ \\
\hline
\end{tabular}

Table 6

Mass conductivity coefficients $k$ calculated by the zonal method for cotton fabric when washing without exposure of ED

\begin{tabular}{c|c|c|c}
\hline Concentration zone number & 1 & 2 & 3 \\
\hline$k_{i} \cdot 10^{10}, \mathrm{~m}^{2} / \mathrm{s}$ & 3,351 & 0,682 & 0,498 \\
\hline $\mathrm{Bi}_{m}$ & 16,0 & 78,7 & 108,0 \\
\hline
\end{tabular}

Table 7

Mass conductivity coefficients $k$ calculated by the zonal method for cotton fabric when washing with exposure of ED

\begin{tabular}{c|c|c|c}
\hline Concentration zone number & 1 & 2 & 3 \\
\hline$k_{i} \cdot 10^{10}, \mathrm{~m}^{2} / \mathrm{s}$ & 4.862 & 0.937 & 0.711 \\
\hline $\mathrm{Bi}_{m}$ & 20.4 & 106.0 & 139.5 \\
\hline
\end{tabular}

Table 8

Mass conductivity coefficients during washing without intensification and with ED

\begin{tabular}{c|c|c|c|c}
\hline \multicolumn{2}{c|}{ Concentration zone number } & 1 & 2 & 3 \\
\hline$k_{i} \cdot 10^{10}, \mathrm{~m}^{2} / \mathrm{s}$ & without ED & 3.351 & 0.682 & 0.498 \\
\hline$k_{i} \cdot 10^{10}, \mathrm{~m}^{2} / \mathrm{s}$ & with ED & 4.862 & 0.937 & 0.711 \\
\hline
\end{tabular}

As can be seen from Table 2, the coefficient of mass conductivity of the fabric when it was washed without ultrasound was about $10^{-10}$, which was consistent with the order of the values of this coefficient in the extraction of target components from the solid phase $[4,5,9]$. With a decrease in the concentration of contaminants, the mass conductivity coefficient decreased slightly. This is probably due to the fact that at the end of the process, the extracted substances were more strongly bound with the structure of the fabric. 
While washing the fabric with ultrasound exposure (Table 3), its mass transfer coefficient in the first three basic concentrations was greater than that without ultrasound exposure (about 1.5 times) and it was on the order of $10^{-9}$. This indicates that ultrasonic pulsation intensifies not only external but also internal mass transfer. In the last zone, the contamination (sodium hydroxide) was removed, which was firmly bound to the solid phase, so ultrasonic pulsations did not affect this connection.

Ultrasonic cavitation, acoustic flows, acoustic pressure, and other effects cause intense turbulent flows both in the entire liquid mass and near the phase boundary, which leads to a significant decrease in the thickness of the diffusion boundary layer $[1,9]$.

The value of the $\mathrm{Bi}_{m}$ number indicates that in the process under consideration in the second period, a mixed-diffusion mass transfer mechanism was implemented, in which both internal and external diffusion resistances influenced the process speed.

The values of the coefficients $\beta_{\mathrm{c}}$ and $k_{i}$ can be used for analysis and kinetic calculation of the washing process of medium-density cotton fabric from sodium hydroxide.

As can be seen from Table 6, the coefficients of mass conductivity during washing of light cotton fabric without intensification were of the order of $10^{-10}$, which was also consistent with the order of the values of this coefficient when extracting the target components from the solid phase.

While washing with an intensifier - ED, the coefficient of mass conductivity in the concentration zones was greater than without it (about 1.5 times).

An increase in all kinetic coefficients indicates that electric discharges, like ultrasound, intensify not only external but also internal mass transfer.

The Bio numbers given in Tables 6 and 7 indicate that in the second period of the process, a mixed-diffusion mass transfer mechanism is realized.

\section{Conclusion}

Based on experimental studies, a quantitative assessment of the influence of physical fields - an ultrasonic field and electric discharges initiated by high voltage pulses in a working solution - on the kinetic coefficients of mass transfer and mass conductivity during washing of light typical cotton fabric and typical medium density cotton fabric after mercerization is given. It is shown that the studied physical fields intensify mass transfer both in the first and in the second periods of the washing process. The values of kinetic coefficients can be used for analysis and kinetic calculation of extraction (washing) processes in the chemical technology of finishing textile materials.

\section{References}

1. Kosheleva M.K. Protsessy $i$ apparaty tekstil'nykh tekhnologiy $v$ primerakh, laboratornykh rabotakh i testakh: uchebnoe posobiye [Processes and apparatuses of textile technologies in examples, laboratory works and tests: textbook. allowance], Moscow: INFRA-M, 2019, 321 p. (In Russ.)

2. Kosheleva M.K., Shchegolev A.A., Shatskikh S.N., Apal'kova M.S. [Intensification of washing processes with the application of ultrasonic fields], Izvestiya vuzov. Tekhnologiya tekstil'noy promyshlennosti [University proceedings. Technology of the textile industry], 2012, no. 3 (339), pp. 113-117. (In Russ., abstract in Eng.)

3. Kosheleva M.K. [Improving the production and environmental safety of the finishing production of fine-woven factories by improving technology], Izvestiya vuzov. Tekhnologiya tekstil'noy promyshlennosti [University proceedings. Technology of the textile industry], 2005, no. 2 (283), pp. 100-105. (In Russ., abstract in Eng.) 
4. Pavlyukevich N.V. Vvedeniye $v$ teoriyu teplo- $i$ massoperenosa $v$ poristykh sredakh [Introduction to the theory of heat and mass transfer in porous media], Minsk: ITMO NAN RB, 2003, 140 p. (In Russ.)

5. Aksel'rud G.A. Massoobmen v sisteme tverdoye telo - zhidkost' [Mass transfer in a solid-liquid system], Lviv: Izdatel'stvo L'vovskogo universiteta, 1970, 187 p. (In Russ.)

6. Rudobashta S.P., Kosheleva M.K., Kartashov E.M. Mathematical Simulation of the Extraction of a Blending Agent from Cylindrical Bodies in the Semicontinuous Regime, Journal of Engineering Physics and Thermophysics, 2016, vol. 89, no. 3, pp. 606-613, doi: 10.1007/s10891-016-1417-5

7. Rudobashta S.P., Kosheleva M.K., Kartashov E.M. Modeling of the Extraction of a Target Component from Bodies of Spherical Shape in a Semicontinuous Process, Journal of Engineering Physics and Thermophysics, 2017, vol. 90, no. 4, pp. 797-805, doi: 10.1007/s10891-017-1628-4

8. Rudobashta S.P., Kosheleva M.K., Kartashov E.M. Nonstationary Mass Transfer Near the Surface of a Cylindrical Body, Journal of Engineering Physics and Thermophysics, 2015, vol. 88, no. 6, pp. 1320-1328, doi: 10.1007/s10891-015-1316-1

9. Romankov P.G., Kurochkina M.I. Ekstragirovaniye iz tverdykh materialov [Extraction from solid materials], Leningrad: Khimiya, 1983, 256 p. (In Russ.)

10. Kazub V.T., PhD Dissertation (Technical), Pyatigorsk, 2002, 345 p. (In Russ.)

11. Kazub V.T., Koshkarova A.G., Tolmacheva A.K. Ustroystvo dlya polucheniya ekstrakta iz sofory yaponskoy [Device for producing extract from Japanese sophora], Russian Federation, 2019, Pat. 2692375. (In Russ.)

12. Kazub V.T., Koshkarova A.G. [Intensification of extraction processes by a pulsed electric field of high tension], Transactions of the Tambov State Technical University, 2014, vol. 20, no. 3, pp. 496-501. (In Russ., abstract in Eng.)

13. Kosheleva M.K., Shatskikh S.N. [Energy-saving mode of extraction of technological pollution from woolen cloths], Transactions of the Tambov State Technical University, 2013, vol. 19, no. 3, pp. 584-592. (In Russ., abstract in Eng.)

14. Reutskiy V.A., Shchegolev A.A., Kosheleva M.K. [Calculation of the washing process during filtration of the washing solution through the fabric], Izvestiya vuzov. Tekhnologiya tekstil'noy promyshlennosti [University proceedings. Technology of the textile industry], 1984, no. 5, pp. 50-54. (In Russ.)

15. Rudobashta S.P., Kosheleva M.K. [Determination of mass transfer and massconductivity coefficients from kinetics curves], Izvestiya vuzov. Tekhnologiya tekstil'noy promyshlennosti [University proceedings. Technology of the textile industry], 2015, no. 6 (360), pp. 175-180. (In Russ., abstract in Eng.)

\section{Влияние физических полей на кинетические коэффициенты в процессе экстрагирования технологических загрязнений из волокнистых материалов}

\section{М. К. Кошелева, М. З. Цинцадзе}

Кафедра «Энергоресурсоэффективные технологии, промышленная экология и безопасность», oxtpaxt@yandex.ru; ФГБОУ ВО «Российский государственный университет им. А. Н. Косыгина (Технологии. Дизайн. Искусство)», г. Москва, Россия

Ключевые слова: импульсы высокого напряжения; кинетика; ультразвуковое поле; хлопчатобумажная ткань; экстрагирование. 
Аннотация: Проведена количественная оценка влияния ультразвукового поля и электрических разрядов, инициируемых импульсами высокого напряжения в рабочем растворе, на кинетические коэффициенты в процессе экстрагирования технологического загрязнения из хлопчатобумажных тканей. Полученные результаты могут использоваться в кинетических расчетах интенсифицированных процессов экстрагирования технологических загрязнений из тканей.

\section{Список литературь}

1. Кошелева, М. К. Процессы и аппараты текстильных технологий в примеpax, лабораторных работах и тестах : учеб. пособие / М. К. Кошелева. - М. : ИНФРА-М, 2019. - $321 \mathrm{c}$.

2. Интенсификация процессов промывки с наложением ультразвуковых полей / М. К. Кошелева, А. А. Щеголев, С. Н. Шацких, М. С. Апалькова // Изв. вузов. Технология текстильной промышленности. - 2012. - № 3 (339). C. $113-117$.

3. Кошелева, М. К. Повышение производственной и экологической безопасности отделочного производства тонкосуконных фабрик за счет совершенствования технологии / М. К. Кошелева // Изв. вузов. Технология текстильной промышленности. - 2005. - № 2 (283). - С. $100-105$.

4. Павлюкевич, Н. В. Введение в теорию тепло- и массопереноса в пористых средах / Н. В. Павлюкевич. - 2-е изд. - Минск : ИТМО НАН РБ, 2003. - 140 с.

5. Аксельруд, Г. А. Массообмен в системе твердое тело - жидкость / Г. А. Аксельруд. - Львов : Изд-во Львовского университета, 1970. - 187 с.

6. Rudobashta, S. P. Mathematical Simulation of the Extraction of a Blending Agent from Cylindrical Bodies in the Semicontinuous Regime / S. P. Rudobashta, M. K. Kosheleva, E. M. Kartashov // Journal of Engineering Physics and Thermophysics. - 2016. - Vol. 89, No. 3. - P. 606 - 613. doi: 10.1007/s10891-016$1417-5$

7. Rudobashta, S. P. Modeling of the Extraction of a Target Component from Bodies of Spherical Shape in a Semicontinuous Process / S. P. Rudobashta, M. K. Kosheleva, E. M. Kartashov // Journal of Engineering Physics and Thermophysics. - 2017. - Vol. 90, No. 4. - P. 797 - 805. doi: 10.1007/s10891-017$1628-4$

8. Rudobashta, S. P. Nonstationary Mass Transfer Near the Surface of a Cylindrical Body / S. P. Rudobashta, M. K. Kosheleva, E. M. Kartashov // Journal of Engineering Physics and Thermophysics. - 2015. - Vol. 88, No. 6. - P. $1320-1328$. doi: 10.1007/s10891-015-1316-1

9. Романков, П. Г. Экстрагирование из твердых материалов / П. Г. Романков, М. И. Курочкина. - Л. : Химия, 1983. - 256 с.

10. Казуб, В. Т. Кинетика и основы аппаратурного оформления процессов электроразрядного экстрагирования биологически активных соединений : дис. ... д-ра техн. наук : 05.17.08 / Казуб Валерий Тимофеевич. - Пятигорск, 2002. - 345 с.

11. Пат. 2692375 Российская Федерация, МПК В01J 19/08, B01D 11/00. Устройство для получения экстракта из софоры японской / В. Т. Казуб, А. Г. Кошкарова, А. К. Толмачева ; заявитель и патентообладатель ФГБОУ ВО «Волгоградский государственный медицинский университет». - № 2018124418 ; заявл. 03.07.2018 ; опубл. 24.06.2019, Бюл. 18. - 7 с.

12. Казуб, В. Т. Интенсификация процессов экстрагирования импульсным электрическим полем высокой напряженности / В. Т. Казуб, А. Г. Кошкарова // Вестн. Тамб. гос. техн. ун-та. - 2014. - Т. 20, № 3. - С. 496 - 501.

13. Кошелева, М. К. Энергоресурсосберегающий режим экстракции технологических загрязнений из шерстяных полотен / М. К. Кошелева, С. Н. Шацких // Вестн. Тамб. гос. техн. ун-та. - 2013. - Т. 19, № 3. - С. 584 - 592. 
14. Реутский, В. А. Расчет процесса промывки при фильтрации моющего раствора сквозь полотно ткани / В. А. Реутский, А. А. Щеголев, М. К. Кошелева // Изв. вузов. Технология текстильной промышленности. - 1984. - № 5. - С. 50 - 54.

15. Рудобашта, С. П. Определение коэффициентов массоотдачи и массопроводности из кривых кинетики / С. П. Рудобашта, М. К. Кошелева // Изв. вузов. Технология текстильной промышленности. - 2015. - № 6 (360). - С. 175 - 180.

\section{Auswirkungen von physikalischen Feldern auf kinetische Koeffizienten im Prozess der Extraktion von technologischen Verunreinigungen aus faserigen Materialien}

Zusammenfassung: Eine quantitative Bewertung des Einflusses des Ultraschallfeldes und der durch Hochspannungsimpulse in der Arbeitslösung ausgelösten elektrischen Entladungen auf die kinetischen Koeffizienten bei der Extraktion der technologischen Verschmutzung aus Baumwollgeweben ist durchgeführt. Die Ergebnisse können für kinetische Berechnungen intensivierter Prozesse zur Extraktion technologischer Verunreinigungen aus Geweben verwendet werden.

\section{Influence des champs physiques sur les coefficients cinétiques lors de l'extraction des contaminants de processus à partir de matériaux fibreux}

Résumé: Est effectuée une estimation quantitative de l'influence du champ ultrasonore et des décharges électriques déclenchées par des impulsions à haute tension dans la solution de travail sur les coefficients cinétiques lors de l'extraction de la contamination technologique des tissus de coton. Les résultats obtenus peuvent être utilisés dans les calculs cinétiques des processus intensifiés d'extraction des contaminants technologiques des tissus.

Авторы: Кошелева Мария Константиновна - кандидат технических наук, доцент, профессор кафедры «Энергоресурсоэффективные технологии, промышленная экология и безопасность»; Цинцадзе Марина Зиевна - аспирант кафедры «Энергоресурсоэффективные технологии, промышленная экология и безопасность», ФГБОУ ВО «Российский государственный университет имени А. Н. Косыгина (Технологии. Дизайн. Искусство)», г. Москва, Россия.

Рецензент: Промтов Максим Александрович - доктор технических наук, профессор кафедры «Технологические процессы, аппараты и техносферная безопасность», декан факультета международного образования, ФГБОУ ВО «ТГТУ», г. Тамбов, Россия. 